\title{
Analysis of upper respiratory tract infections in mission circumstances
}

\author{
FEJES Zsolt ${ }^{1}$, KORODI Gyula ${ }^{2}$
}

\begin{abstract}
During this research a specific partial data set of the UN database was analyzed from different aspects and evaluated in order to create an image about the prevalence and probable reasons of upper respiratory tract infections among soldiers serving in the operation area.

The research indicates that the prevalence of upper respiratory tract infections (URTIs), and the previously performed tonsillectomies, was the highest in one contingent. The statistical data demonstrates that the tonsillectomies may influence the frequency of upper respiratory infections within the contingent.
\end{abstract}

\section{Introduction}

The objective of the study was to process the accumulated medical database of the United Nations Peacekeeping Forces in Cyprus (UNFICYP) and make an analysis of URTIs among military troops.

\section{Discussion}

Analysis of the UN medical database has demonstrated that the prevalence of different illnesses varies between nationalities. [1] Dental and stomatological problems are most common within the Argentinean contingent (ARG), whereas the most dominant problems among the British contingent (BRIT) are musculoskeletal and sports injuries. Within the Hungarian contingent (HUN), the most common medical problems are URTIs. [1]

In order to explain why the highest rate of URT was among the Hungarian soldiers in the mission, we looked for medical and microbiological connections.

\section{Research methods}

During the research a specific partial data set of the local, UNFICYP database was analyzed from different aspects. The analysis was made with the co-operation of soldiers in the United Nations Peacekeeping Force in Cyprus (UNFICYP), from four nations - Argentina, the United Kingdom, Hungary and Slovakia - using data between 2009 and 2012.

Considering that the countries select the participants of the mission based on standard methods and requirements we examined a homogenous, healthy population looking at age, work, working conditions, and general physical conditions. The standard system that created the sta-

1 Military Hospital, Medical Centre, Hungarian Defence Forces, Budapest, Hungary

2 National University of Public Service, Institute of Disaster Management, Budapest, Hungary 
tistical basis of the research is provided by the UN standardized data processing and reporting system. [2] The research was made with three different methods and the following phases:

\section{Retrospective data acquisition, statistical analysis}

Medical records from $1^{\text {st }}$ January, 2009 to $31^{\text {st }}$ December, 2012 have been analyzed. This consists of data from troops from four contingents: Argentina (ARG), United Kingdom (BRIT), Slovakia (SLOV), and Hungary (HUN). After the primary analysis of 15,749 diagnosed cases, 2,521 URTIs were identified and highlighted for further process and study.

\section{Survey}

Surveying was also completed with the participation of all four contingents. This survey aimed to determine the proportion of patients with and without tonsillectomies within each national contingent. Almost 600 questionnaires were evaluated and ear, nose and throat physical examinations were carried out.

\section{Microbiological laboratory examination}

Microbiological laboratorial examinations — throat swabs [3] — were performed in 200 cases in order to detect the differences in quality and quantity of the oral bacterial flora.

\section{Results in connection with URTIs}

We found out that, among all the registered diagnostic groups of diseases in mission level, the rate of URT-infections was between $17 \%$ and $21 \%$ annually. The numbers of the URTIs over the 4 years are without any peak. We found out that the rate of URTIs was highest among the Hungarian contingent. This observation is true for each of the 4 years. (Table 1.)

\begin{tabular}{|c|c|c|c|c|}
\hline Year & ARG & BRIT & SLOV & HUN \\
\hline 2009 & $15 \%$ & $26 \%$ & $13 \%$ & $30 \%$ \\
\hline 2010 & $14 \%$ & $16 \%$ & $11 \%$ & $26 \%$ \\
\hline 2011 & $17 \%$ & $17 \%$ & $11 \%$ & $28 \%$ \\
\hline 2012 & $14 \%$ & $11 \%$ & $11 \%$ & $32 \%$ \\
\hline
\end{tabular}

Table 1. Rate of upper respiratory affections in the mission between 2009-2012

\section{Results in connection with group of diagnosis}

The URTI group was separated into two further diagnostic sub-groups:

Group 1- Infections with cold-like symptoms:

acute rhinitis, allergic rhinitis, rhino-sinusitis

Group 2 - Infections with throat pain symptoms:

pharyngitis, tonsillitis 
We further examined how URTIs were spread across the two diagnostic groups. Considering both the data of the whole mission, and the reduced data of each contingent, Group 1 was affected, as a proportion, more than Group 2. (Table 2.)

\begin{tabular}{|c|c|c|c|c|}
\hline Diagnostic-groups & 2009 & 2010 & 2011 & 2012 \\
\hline No.1 group & $70 \%$ & $68 \%$ & $77 \%$ & $68 \%$ \\
\hline No.2 group & $30 \%$ & $32 \%$ & $23 \%$ & $32 \%$ \\
\hline
\end{tabular}

Table 2. Prevalence of URTIs within the diagnostic-groups between 2009-2012

\section{Results in connection with number of cases per 100 capita}

We specified the number of cases and diagnoses per capita using an Upper Respiratory Tract Score.

Statistical analysis highlighted that, comparing different medical indexes and diagnosis-frequency, both subgroups of URT-infections were in the highest proportion among the Hungarian soldiers during the surveyed four years. (Table 3.)

\begin{tabular}{|l|c|c|c|c|}
\hline & ARG & BRIT & SLOV & HUN \\
\hline Mean of the URT Score & 0,6 & 0,8 & 0,5 & 1,3 \\
\hline Rate of number of cases per 100 capita & 60 & 80 & 50 & 130 \\
\hline
\end{tabular}

Table 3. Mean of the URT Score of four contingents

\section{Results in connection with tonsillectomy}

We could not disregard the fact that certain previous surgical interventions, like adenotomies or tonsillectomies, may affect the current medical status, and thus may influence the prevalence of URT-infections among solders. Because of this possible connection, we extended our research to the qualitative and quantitative processing of the previously performed operations whereby we analyzed the operations in relation to two main groups:

- Throat-related interventions (adenotomy and tonsillectomy)

- Other operations (all operations except the above mentioned two)

According to the results of the survey $47 \%$ of the Argentine contingent, $55 \%$ of the Brit contingent and $53 \%$ of the Slovakian contingent mentioned some kind of previous surgical intervention, while $57 \%$ of the Hungarian contingent mentioned the same.

According to the processed data of the previously performed surgeries, $20 \%$ of the Argentinean contingent had undergone a tonsillectomy, 64\% among the British soldiers, and 24\% among the Slovakian soldiers. The rate among the Hungarian soldiers was $65 \%$.

Next we analyzed the operations according to their dates and types (performed operations in childhood or in adulthood; adenotomy or tonsillectomy, or combined tonsillo- adenotomy). We stated that the typical intervention among Hungarian soldiers was the tonsillectomy in adulthood while interventions in childhood dominated among the other three contingents. (Table 4.) 


\begin{tabular}{|c|c|c|c|c|c|c|}
\hline $\begin{array}{c}\text { Contin- } \\
\text { gents }\end{array}$ & $\begin{array}{c}\text { No } \\
\text { previous } \\
\text { operations }\end{array}$ & $\begin{array}{c}\text { Had } \\
\text { previous } \\
\text { operations }\end{array}$ & $\begin{array}{c}\text { Other } \\
\text { operations }\end{array}$ & $\begin{array}{c}\text { ENT } \\
\text { operations }\end{array}$ & $\begin{array}{c}\text { Tonsillec- } \\
\text { tomy in } \\
\text { childhood }\end{array}$ & $\begin{array}{c}\text { Tonsillec- } \\
\text { tomy in } \\
\text { adulthood }\end{array}$ \\
\hline ARG & $53 \%$ & $47 \%$ & $80 \%$ & $20 \%$ & $87 \%$ & $13 \%$ \\
\hline BRIT & $45 \%$ & $55 \%$ & $36 \%$ & $64 \%$ & $91 \%$ & $9 \%$ \\
\hline SLOV & $47 \%$ & $53 \%$ & $76 \%$ & $24 \%$ & $89 \%$ & $11 \%$ \\
\hline HUN & $43 \%$ & $57 \%$ & $35 \%$ & $65 \%$ & $71 \%$ & $29 \%$ \\
\hline
\end{tabular}

Table 4. Rate of operations among contingents

According to the hypothesis based on the present results, termination of the protective role of pharyngeal tonsils - which is an intervention altering the protective system, microbiological integrity, anatomical and functional status of the organism — could influence the number of acute URT-infections. [4]

As a consequence of the results of the data in our research material we found out that after the termination of pharyngeal tonsils the number of URT-infections in adulthood increases without any known reason. This assumption was proved indirectly by the fact that in our research the URT-infections have less prevalence among those people who still have their tonsils. We assumed that there was a traceable relation between tonsillectomies and the frequency of URT-infections in adulthood. We thought that in those cases where pharyngeal tonsillectomies had been performed oro-pharyngeal bacterial flora were changed without any known reason and the protective function without the functions of the tonsils was decreased assisting the colonization of certain pathogens along with increasing the frequency of URT-infections. [5]

\section{Microbiological results}

Towards proving the theory, confirming its microbiological reasons and showing the direct relations we took throat swab samples from 200 patients and performed microbiological analyses. The examinations were performed on an equal number of soldiers with tonsillectomies and without tonsillectomies. From the 500 pathogens, which create the oral bacterial flora, we were focused on 15-20 bacteria. [6]

From the 200 samples, which were sent for microbiological analyses 68 samples had positive results (10 phyla, 5 subtypes, 1 fungus were detected), which means 34\% positive samples all in all. In the group with a tonsillectomy the number of human pathogens was double (+28) than in the control group under the same number of cases. Among the detected pathogens all have major roles in causing those disease-groups of URT-infections, which we examined.

Among those 100 patients with a tonsillectomy and among the 100 patients of the control group the following pathogens were detected. (Table 5.) 
FEJES Zsolt, KORODI Gyula: Analysis of upper respiratory tract infections in mission circumstances

\begin{tabular}{|l|l|c|c|c|}
\hline Name of the pathogen & $\begin{array}{c}\text { Group with } \\
\text { tonsillectomies }\end{array}$ & $\begin{array}{c}\text { Control } \\
\text { Group }\end{array}$ & $\begin{array}{c}\text { Dis- } \\
\text { crepancy }\end{array}$ \\
\hline 1 & Staphylococcus aureus & 13 & 4 & +9 \\
\hline 2 & MRSA & 2 & 0 & +2 \\
\hline 3 & Streptococcus & 9 & 3 & +6 \\
\hline 4 & Pseudomonas aeruginosa & 2 & 0 & +2 \\
\hline 5 & Acinetobacter & 2 & 2 & 0 \\
\hline 6 & E.coli & 5 & 2 & +3 \\
\hline 7 & Enterobacter cloacae & 4 & 4 & 0 \\
\hline 8 & Lactobacillus & 0 & 3 & -3 \\
\hline 9 & Klebsiella pneumonia & 4 & 3 & +1 \\
\hline 10 & Serratia & 1 & 0 & +1 \\
\hline 11 & Pantoea agglomerans & 0 & 1 & -1 \\
\hline 12 & ESBL & 0 & 0 & 0 \\
\hline 13 & Candida albicans & 4 & 0 & +4 \\
\hline & Total & 46 & 22 & +28 \\
\hline
\end{tabular}

Table 5. Detected pathogens in throat swabs

Discrepancy of the detected pathogens among soldiers with a tonsillectomy was more significant than in the control group. Especially if we take into consideration that, under the same number of cases, the numbers of the detected human pathogens [7] was double among soldiers with a tonsillectomy compared to soldiers in the control group without tonsillectomy.

\section{Summary}

The rate of the URT-infections and tonsillectomy was the highest among the Hungarian contingent. According to the processed statistical data, it is proven that the examined factor has a dominant role in the frequently occurred URT-infections among Hungarian soldiers.

Termination of the protective function of pharyngeal tonsils could cause the presence and colonization of certain pathogens in pharyngeal area. In our research the pathogens detected from microbiological samples exceeded in numbers more significantly among soldiers with a tonsillectomy than among the solders without a tonsillectomy. As a direct correlation it is verifiable that the presence of the pathogens in greater numbers in the pharyngeal area could cause the frequent URT-infections. Through the results of our research it is detectable that certain bacteria, which are basically part of the normal and healthy throat-microflora, appear more often among patients without tonsils, while others typically colonize in patients' pharyngeal area that still have their tonsils. All this could mean a microbiological correlation between the different aptness for URT-infections among patients with a tonsillectomy and patients without a tonsillectomy. 
FEJES Zsolt, KORODI Gyula: Analysis of upper respiratory tract infections in mission circumstances

\section{References}

[1] UNFICYP: Monthly Medical Reports. UNFICYP-internal-use document, 2009-2012.

[2] Medical Support Manual for United Nations Peacekeeping Operations. Health Care Policies and Procedures. 1999, 45-48.

[3] National Library of Medicine, National Institue of Health. http://www.nlm.nih.gov/ medlineplus/ency/article/003746.htm (downloaded 1010 2013)

[4] VEGA, C. P.: Is Tonsillectomy Effective for Adults With Recurrent Pharyngitis? http://www.medscape.org/viewarticle/802984. (downloaded: 1010 2013)

[5] National Library of Medicine, National Institue of Health. http://www.nlm.nih.gov/ medlineplus/ency/article/000639.htm (downloaded: 1210 2013)

[6] TODAR, K.: Todar's Online Textbook of Bacteriology. http://textbookofbacteriology.net/ normalflora.html (downloaded: 1410 2013)

[7] TODAR, K.: Todar's Online Textbook of Bacterology. http://textbookofbacteriology.net/ medical_4.html (downloaded: 1510 2013) 